\title{
Functional capacity and reported morbidities: a comparative analysis in the elderly
}

William César Gavasso?

Vilma Beltrame'

\section{Abstract}

Objective: To evaluate the influence of chronic morbidities on the functional capacity of elderly persons living in the municipal region of Herval d' Oeste, in the state of Santa Catarina, Brazil. Methods: An analytical cross-sectional study was carried out with a sample of 272 elderly people registered in the Family Health Strategy of the municipality of Herval d' Oeste, Santa Catarina. A socio-demographic questionnaire, Katz's Basic Activities of Daily Living Scale and Lawton's Instrumental Activities of Daily Living Scale (IALD) were used as instruments to gather data. The socio-demographical variables were estimated in frequencies and percentages. The associations were analyzed through the chi-square test. Results: Significant statistical associations for dependence were only found in the IADL assessments. Hypertension and Diabetes Mellitus were not found to influence the dependence of the elderly. However, a greater number of elderly persons who reported pathologies of the gastrointestinal system were classified as dependent. While the number of morbidities did not influence dependence in IADL, there was a smaller percentage difference between dependent and independent individuals among those with more than three morbidities. Conclusion: No relationship was found between the number of morbidities and the functional and instrumental capacity of the elderly. However, diseases of the gastrointestinal system demonstrated an influence on the dependence of elderly persons of Herval d'Oeste, Santa Catarina.

Universidade do Oeste de Santa Catarina (UNOESC), Programa de Mestrado em Biociências e Saúde (PGBiocS), Grupo de Pesquisa Promoção e Gestão em Saúde. Joaçaba, SC, Brasil.

Correspondence

William César Gavasso

E-mail: william.gavasso@unoesc.edu.br

Keywords: Chronic Disease. Aging. Health Services for the Aged. Frail Elderly. Interdisciplinary Studies. 


\section{INTRODUCTION}

Brazil is undergoing a process of population aging, caused mainly by a reduction in the birth rate and an increase in life expectancy ${ }^{1}$. When they reach old age, human beings undergo significant physical changes that if unstructured can characterize a strong risk factor for the development of disabilities ${ }^{2}$.

The assessment of individual levels of independence in Activities of Daily Living (ADLs) and Instrumental Activities of Daily Living (IADLs) determine the ability of an individual to take care of themselves and to live independently, respectively. ADLs explore the individual's abilities to meet basic hygiene, dressing, using the bathroom and movement and transfer needs. IADLs, meanwhile, examine activities that characterize independence in the community such as preparing meals, using the telephone, shopping, using medications safely, cleaning, walking, and managing finances ${ }^{3}$.

The presence of chronic disease is commonly observed in the elderly. It does not necessarily characterize the appearance or otherwise of disabilities, however, but represents a relevant factor for their development. Despite the physiological aspects of the development of morbidities, the identification of factors that can accelerate the loss of functional capacity constitutes an effective tool for the development and implementation of actions directed towards the elderly ${ }^{4}$.

From a preventive perspective, primary health care functions as a key tool in the maintenance of functional capacity, since it represents the main strategy in the prevention of chronic disease related damage to health, which can lead to loss of functional capacity. Family Health Strategies support the prevention of disabilities by assessing, monitoring, preventing and, if necessary, intervening in the cases of elderly persons who are at a greater risk for loss of autonomy ${ }^{1}$.

Due to the population aging process, and the demands on health services to meet the growing range of chronic diseases, there is a need for a study focusing on functional disability and its relation to the physical characteristics and morbidities of the aging process.
The evaluation of the functional and instrumental capacity of the elderly and knowledge of their chronic morbidities is one of the tools that can support the actions of the health services, as maintaining independence results in the improvement of the living conditions of this population.

In view of the above, the present study aimed to evaluate the influence of chronic morbidity on functional capacity among the elderly living in the municipal region of Herval d'Oeste, in the state of Santa Catarina, Brazil.

\section{METHODS}

The data were obtained through a quantitative, analytical, cross-sectional study of people over 60 years of age enrolled in the Family Health Strategy (FHS) units of the municipal region of Herval d'Oeste, Santa Catarina, Brazil, in the period May to October 2015.

The municipal region is located in the middle of the state of Santa Catarina, and is an important producer of alfalfa with a strong economic base in agriculture and agribusiness. According to IBGE $^{5}$ estimates for the year 2013, it has 22,083 inhabitants, of whom 2,923 are over 60 years of age. To calculate the sample size, a margin of error of $5 \%$ was considered, with a 95\% confidence interval and a $50 \%$ response distribution, resulting in 272 elderly subjects to be interviewed. A simple draw method was used for selection, giving the same opportunity of inclusion to the entire population.

The inclusion criteria were: age 60 years of age or older, of both genders, assigned to a Family Health Strategy (FHS) unit in the municipal region. The responses of subjects who met the inclusion criteria but who had accentuated cognitive and/or intellectual deficits, were bedridden, in a vegetative state or, due to any pathological process, were unable to respond to the instruments, were given by their caregivers.

A questionnaire with sociodemographic, epidemiological and morbidity information of the Projeto Porto Alegre (the Porto Alegre Project), of the Pontífica Universidade Católica of Rio Grande do Sul (the Pontifical Catholic University of Rio Grande do Sul) was used for data collection. It included 
data on the health, profile and morbidities used for the study. The dependent variables were the functional capacity of the elderly, measured using the Katz Scale of Basic Activities of Daily Living (BADLs) and the Lawton Instrumental Activities of Daily Living Scale (IADLs), which were classified as dependent or independent for both dimensions. did not report difficulties in the performance of any of the BADL and IADL, and dependent when they determined a difficulty in at least one activity in any of the dimensions.

The independent variables were the sociodemographic data and the chronic morbidity factors identified. Gender, marital status, age and schooling were considered. Age was assessed as a continuous variable. Marital status was described as married, widowed, single, separated. Level of schooling was characterized as illiterate, out of school literacy, $1^{\text {st }}$ to $4^{\text {th }}$ grade of fundamental level, $5^{\text {th }}$ to $8^{\text {th }}$ grades of fundamental level, high school, higher education and additional education. Chronic diseases were characterized based on previously diagnosed pathologies receiving treatment in basic care. Measurements were made based on affirmative answers regarding the presence or absence of hypertension, diabetes mellitus, dyslipidemias (cholesteremias), gastrointestinal disorders, thyroiditis and other related morbidities. The diseases of the gastrointestinal tract considered were: gastritis, peptic ulcer, neoplasia of the gastrointestinal tract, diseases of the intestinal tract. Thyroiditis was considered as hypo and hyperthyroidism. The other morbidities group includes those that were reported by a maximum of three subjects in the research.

The interviews took place at the homes of the selected subjects, with the participation of two assistant researchers, in addition to the principal investigator, to carry out data collection. The assistants received prior training in the methods and application of each instrument.

To estimate the association between functional capacity, the analysis of basic and instrumental activities of daily living, and chronic diseases, association and independence tests were used.

The socio-demographic variables were initially calculated in frequencies and percentages. The association between the dependent and independent variables was analyzed through the chi-square test, with reliability tested by Cronbach's Alpha and the normality of the total score with the KolmogorovSmirnov test.

The results of the model were presented as the percentage ratio, divided into dependents and independent, seeking the association between the presence of dependence and the morbidity reported by the subject. The results obtained from the BADL and IADL analyzes were classified by statistical significance analysis models and compared with the number and types of reported morbidity. In all tests the level of significance considered was $5 \%$. The present study was approved by the Research Ethics Committee of the Universidade do Oeste de Santa Catarina de Joaçaba (the University of West Santa Catarina in Joaçaba), Santa Catarina (protocol $n^{\circ}$ 917.074). All the participants signed a Free and Informed Consent Form (FICF).

\section{RESULTS}

A total of 272 elderly people living in the municipal region of Herval d'Oeste, Santa Catarina, were interviewed regarding demographic and social variables. There were $68.8 \%(\mathrm{n}=187)$ females and $31.2 \%(\mathrm{n}=85)$ males. Age ranged from 60 to 98 years among women, with a mean age of 73.1 ( \pm 8.3 years), and 60 to 100 years among men, with a mean age of 71.1 ( \pm 8.1 years). There was a higher prevalence of married individuals $(\mathrm{n}=152)$ and those with an elementary school education $(\mathrm{n}=176)$. 
Table 1. Characterization of sample in terms of demographic and social variable of elderly persons. Herval d'Oeste, Santa Catarina, 2015.

\begin{tabular}{|c|c|}
\hline Variables & $\mathrm{n}(\%)$ \\
\hline \multicolumn{2}{|l|}{ Sex } \\
\hline Female & $187(68.8)$ \\
\hline Male & $85(31.2)$ \\
\hline \multicolumn{2}{|l|}{ Marital status } \\
\hline Married & $152(55.9)$ \\
\hline Widower & $81(29.8)$ \\
\hline Not married & $20(7.4)$ \\
\hline Separated & $19(7.0)$ \\
\hline \multicolumn{2}{|l|}{ Age Range (years) } \\
\hline $60-69$ & $112(41.2)$ \\
\hline $70-79$ & $105(38.5)$ \\
\hline $80-89$ & $48(17.6)$ \\
\hline 90 or more & $7(2.7)$ \\
\hline \multicolumn{2}{|l|}{ Schooling } \\
\hline Illiterate & $23(8.5)$ \\
\hline Out of school literacy & $13(4.8)$ \\
\hline 1st to 4th grade of elementary school & $176(64.7)$ \\
\hline 5th to 8th grade of elementary school & $43(15.9)$ \\
\hline High school & $8(3.0)$ \\
\hline Incomplete higher education & $7(2.5)$ \\
\hline Additional & $2(0.6)$ \\
\hline
\end{tabular}

The prevalence of independence was $84.2 \%$ in BADL and $70.2 \%$ in IADL, demonstrating that the elderly in this study are mostly independent in these two assessments.

In terms of the differences in the degrees of dependence for BADL and IADL between genders, men were most dependent in the dressing function $(8.2 \%)$, while women were most dependent in the continence function $(13.9 \%)$. In the frequency distribution of the degree of dependence according to the Katz and Lawton scales (BADL and IADL), the frequency of independence was higher in BADL, varying from $91.8 \%$ to $96.5 \%$, than in IADL, where it ranged from $75.7 \%$ to $88.2 \%$.
The greatest prevalence of totally dependent elderly persons was for the bathing activity $(4.8 \%)$ of BADL, and the managing finances activity $(12.8 \%)$ of IADL. In the association between chronic conditions and degree of dependency in BADL and IADL, the most frequent chronic condition was Arterial Hypertension, which was the most prevalent morbidity among dependent elderly persons, with $11.8 \%$ in BADL and $22.8 \%$ in IADL. Systemic arterial hypertension $(p=0.018)$ and diabetes mellitus $(p=0.023)$ had no influence on IADL, with most elderly persons with these morbidities being considered independent. However, the majority of the elderly who reported gastrointestinal system disorders (4\%) were dependent in the instrumental evaluation (IADL) $(p=0.015)$. 
Table 2. Distribution of dependency by gender according to Katz Scale. Herval d'Oeste, Santa Catarina, 2015.

\begin{tabular}{lllll}
\hline Variables & $\begin{array}{l}\text { Men Independent } \\
\mathrm{n}(\%)\end{array}$ & $\begin{array}{l}\text { Men Dependent } \\
\mathrm{n}(\%)\end{array}$ & $\begin{array}{l}\text { Women Independent } \\
\mathrm{n}(\%)\end{array}$ & $\begin{array}{l}\text { Women Dependent } \\
\mathrm{n}(\%)\end{array}$ \\
\hline Function & & & & \\
Bathing & $79(92.9)$ & $6(7.1)$ & $166(88.8)$ & $21(11.2)$ \\
Dressing & $78(91.8)$ & $7(8.2)$ & $173(92.5)$ & $14(7.5)$ \\
Go to the bathroom & $81(95.3)$ & $4(4.7)$ & $177(94.6)$ & $10(5.3)$ \\
Transfer & $81(95.3)$ & $4(4.7)$ & $173(92.5)$ & $14(7.5)$ \\
Continence & $80(94.1)$ & $5(5.9)$ & $161(86.1)$ & $26(13.9)$ \\
Feeding & $82(96.5)$ & $3(3.5)$ & $178(95.2)$ & $9(4.8)$ \\
\hline
\end{tabular}

Table 3. Distribution of the frequency of degree of dependence according to the Katz and Lawton Scales (Activities of Daily Living and Instrumental Activities of Daily Living) in the elderly. Herval d'Oeste, Santa Catarina, 2015.

\begin{tabular}{llll}
\hline Activity & Independent & $\begin{array}{l}\text { With some type of } \\
\text { assistance } \\
\mathrm{n}(\%)\end{array}$ & $\begin{array}{l}\text { Totally Dependent } \\
\mathrm{n}(\%)\end{array}$ \\
\hline Basic Activities of Daily Living & $245(90.1)$ & $14(5.1)$ & $13(4.8)$ \\
Bathing & $250(91.9)$ & $10(3.7)$ & $12(4.4)$ \\
Dressing & $258(94.9)$ & $8(2.9)$ & $6(2.2)$ \\
Go to the bathroom & $254(93.4)$ & $14(5.1)$ & $4(1.5)$ \\
Transfer & $241(88.6)$ & $30(11)$ & $1(0.4)$ \\
Continence & $260(95.6)$ & $6(2.2)$ & $6(2.2)$ \\
Feeding & $240(88.2)$ & & $11(4.0)$ \\
\hline Instrumental Activities of Daily Living & $219(80.5)$ & $21(7.7)$ & $21(7.7)$ \\
Use the phone & $217(79.8)$ & $32(11.8)$ & $28(10.3)$ \\
Use means of transport & $237(87.1)$ & $27(9.9)$ & $24(8.8)$ \\
Shopping & $232(85.3)$ & $11(4.0)$ & $28(10.3)$ \\
Preparing Meals & $225(82.7)$ & $12(4.4)$ & $26(9.6)$ \\
Clean the house & $231(84.9)$ & $10(3.7)$ & $31(11.4)$ \\
Manual Tasks & $225(82.7)$ & $19(7.0)$ & $28(10.3)$ \\
Laundry & $206(75.7)$ & $31(11.4)$ & $35(12.9)$ \\
Taking Medication & & & \\
Managing Finances & & & \\
\hline
\end{tabular}

In the association between degree of dependence for BADL and IADL and number of referred morbidities, the evaluation of BADL did not present a significant result ( $p=0.097)$. There was greater dependence in BADL for those who had two morbidities (7\%).

In the evaluation of IADL, no relationship was found between dependence and the morbidities reported by the elderly ( $p=0.002)$, and there was a predominance of independent elderly persons in all the associations analyzed. The highest percentage of dependent elderly persons in this evaluation were those who reported two morbidities (9.9\%). It was observed that elderly persons with three or more morbidities exhibited greater dependence, as the percentage difference between dependent and independent individuals fell as the number of reported morbidities increased. 
Table 4. Association between chronic condition and degree of dependence in the performance of Activities of Daily Living and the Scale of Instrumental Activities of Daily Living among the elderly. Herval d'Oeste, Santa Catarina, 2015.

\begin{tabular}{|c|c|c|c|c|c|c|}
\hline \multirow[b]{2}{*}{ Chronic Condition } & \multicolumn{3}{|c|}{ Basic Activities of Daily Living } & \multicolumn{3}{|c|}{ Instrumental Activities of Daily Living } \\
\hline & $\begin{array}{l}\text { Dependent. } \\
\mathrm{n}(\%)\end{array}$ & $\begin{array}{l}\text { Independent. } \\
\mathrm{n}(\%)\end{array}$ & $p^{*}$ & $\begin{array}{l}\text { Dependent. } \\
\mathrm{n}(\%)\end{array}$ & $\begin{array}{l}\text { Independent. } \\
\mathrm{n}(\%)\end{array}$ & $p^{*}$ \\
\hline \multicolumn{7}{|c|}{ Arterial Hypertension } \\
\hline Yes & $32(11.8)$ & $159(58.6)$ & & $62(22.8)$ & $129(47.4)$ & \\
\hline No & $11(4.0)$ & $70(25.7)$ & 0.236 & $19(7.0)$ & $62(22.8)$ & 0.018 \\
\hline \multicolumn{7}{|l|}{ Diabetes Mellitus } \\
\hline Yes & $13(4.8)$ & $38(14.0)$ & & $20(7.4)$ & $31(11.4)$ & \\
\hline No & $30(11.0)$ & $191(70.2)$ & 0.082 & $61(22.4)$ & $160(58.9)$ & 0.023 \\
\hline \multicolumn{7}{|l|}{ Dyslipidemia } \\
\hline Yes & $9(3.3)$ & $60(22.1)$ & & $23(8.5)$ & $46(16.9)$ & \\
\hline No & $34(12.5)$ & $169(62.1)$ & 0.429 & $58(21.3)$ & $145(53.3)$ & 0.06 \\
\hline \multicolumn{7}{|l|}{ Gastrointestinal } \\
\hline Yes & $5(1.8)$ & $15(5.5)$ & & $11(4.0)$ & $9(3.3)$ & \\
\hline No & $38(14)$ & $214(78.7)$ & 0.158 & $70(25.7)$ & $182(66.9)$ & 0.015 \\
\hline \multicolumn{7}{|l|}{ Thyroiditis } \\
\hline Yes & $8(3.0)$ & $17(6.3)$ & & $12(4.4)$ & $13(4.8)$ & \\
\hline No & $35(12.7)$ & $212(78.0)$ & 0.219 & $69(25.4)$ & $178(65.4)$ & 0.078 \\
\hline \multicolumn{7}{|l|}{ Others } \\
\hline Yes & $19(7.0)$ & 40 (14.6) & & $57(21.0)$ & $32(11.8)$ & \\
\hline No & $24(8.9)$ & $189(69.5)$ & 0.219 & $50(18.4)$ & $133(48.9)$ & 0.078 \\
\hline
\end{tabular}

* Chi-square test.

Table 5. Association between degree of dependence (for the realization of Activities of Daily Living and the Scale of Instrumental Activities of Daily Living) and the numbers of morbidities reported by the elderly. Herval d'Oeste, Santa Catarina, 2015.

\begin{tabular}{|c|c|c|c|c|c|c|}
\hline \multirow[b]{2}{*}{$\begin{array}{l}\text { Number of } \\
\text { morbidities reported }\end{array}$} & \multicolumn{2}{|c|}{ Functional Capacity } & \multirow[b]{2}{*}{$p^{*}$} & \multicolumn{3}{|c|}{ Instrumental Capacity } \\
\hline & $\begin{array}{l}\text { Dependent. } \\
\mathrm{n}(\%)\end{array}$ & $\begin{array}{l}\text { Independent. } \\
\mathrm{n}(\%)\end{array}$ & & $\begin{array}{l}\text { Dependent. } \\
\mathrm{n}(\%)\end{array}$ & $\begin{array}{l}\text { Independent. } \\
\mathrm{n}(\%)\end{array}$ & $p^{*}$ \\
\hline None & $5(1.8)$ & $36(13.2)$ & 0.097 & $6(2.2)$ & $35(12.9)$ & \\
\hline One & $10(3.7)$ & $83(30.5)$ & & $23(8.5)$ & $70(25.7)$ & 0.002 \\
\hline Two & $19(7.0)$ & $64(23.5)$ & & $27(9.9)$ & $56(20.6)$ & \\
\hline Three or more & $10(3.7)$ & $45(16.5)$ & & $23(8.5)$ & $32(11.7)$ & \\
\hline Total & 43 & 229 & & 79 & 193 & \\
\hline
\end{tabular}

*Chi-square test.

\section{DISCUSSION}

It is important to start this discussion by stating that the elderly represent $12 \%$ of the Brazilian population. However, projections indicate that this group will reach $38 \%$ in 2060 , demonstrating a strong trend in the increase of life expectancy of Brazilians and the number of elderly people ${ }^{4,5}$.

The elderly in this study were predominantly aged 60 to 69 years, $20.3 \%$ of whom were older than 80 years. This result characterizes a long-lived 
population. Increased longevity may imply a greater number of elderly individuals at risk for disability and the development of morbidities ${ }^{6,7}$.

The present study found a higher percentage of elderly women. This result is higher than the average for Brazil and for the state of Santa Catarina other studies, where the average proportion of women was always above $60 \% \%^{1,6,8}$.

This characterizes what gerontology scholars call the "feminization of old age," which especially occurs in more advanced ages. Factors such as behavior, work characteristics and genetic characteristics can be highlighted as preponderant for the greater numbers of women at these ages, although the main reason for this phenomenon is the care that women take of their health. Women seek health services more often and are able to live longer with disabilities and diseases, resulting in lower mortality ${ }^{9-12}$.

In general, the participants in this study were more dependent in IADL than BADL. It was found that few elderly people exhibited total dependence in their evaluations, which is similar to other studies in this $\operatorname{area}^{13-16}$.

Camargos et al. ${ }^{4}$ considered the evaluation of functional and instrumental capacity as important tools in health planning, as such analysis makes it possible to identify and improve the expectancy of years of live without disabilities, aiming not at treatment but at improving the quality of life of the person being evaluated.

The activities in which the elderly most described dependence in the evaluation of BADL were bathing, dressing and continence. Women exhibited greater dependence than men. Women were more dependent in continence while men were more dependent in dressing.

Barbosa et al. ${ }^{14}$ found that women are usually more dependent, especially in BADL. This result was similar to that obtained by Fernandes ${ }^{17}$ and Gasparini $^{18}$, who identified a greater dependence in continence in both genders. Other studies also highlight incontinence, especially urinary incontinence, as an important factor of dependence in women ${ }^{14,15}$.

Incontinence is a change that affects women more frequently, becoming a constant problem in clinical practice, especially in elderly women. It is commonly due to several interventions in the perineal region, especially due to multiple births ${ }^{19}$.

In terms of the evaluation of men, there was greater dependence in the activity of self-care. This type of relationship of dependence was not observed in men in other research. These studies found that while women are more dependent than men, the forms of male dependence result in a greater need for direct care from a caregiver, as they are more severe levels of dependence ${ }^{20,21}$.

Britto et al..$^{20}$ found that women have a 1.5 times greater rate of dependency than men, with this outcome attributed to longer life expectancy and a greater ability to live with non-fatal disabilities such as depression, fractures and osteoporosis.

The BADL where the elderly persons of Herval d'Oeste, Santa Catarina, exhibited greater dependence was bathing. Costa et al. ${ }^{22}$ found a similar result in their study, where the highest levels of dependence in the evaluation of functional capacity were for bathing. However, the proportion of dependent individuals in this study was higher than in the present study.

While the dependency profile of the present study was similar to other studies in this field ${ }^{22,23}$, the percentage of dependents was lower.

The elderly were most dependent in the instrumental activities managing their own finances and making purchases alone. This finding differed from the result obtained by Barbosa et al. ${ }^{14}$, where the items of greatest dependence were travelling distant places alone, followed by washing the dishes, ironing and using the telephone (to make calls).

Fialho et al. ${ }^{13}$, meanwhile, also identified a reduced capacity for the activity of making purchases, with limitations in domestic tasks the second most dependent item.

Some studies identified a significant prevalence of dependence in the management of finances and the obtaining of consumer goods activities. The elderly tend to begin the process of dependency when they 
need help to take care of their money or buy some type of consumer product ${ }^{20,24-26}$.

From this it can be affirmed that the elderly of the present study require care from health teams both in terms of their access to services and the preservation of their financial autonomy. These dependencies may also be related to the low level of schooling identified, since, as Santos and Cunha ${ }^{24}$ state, financial dependence is directly related to knowledge of the use of technologies that give access to the withdrawal of money and its use in commercial locations. They further add that the extent to which an elderly person becomes dependent in these items reflects in the loss of their autonomy.

In comparison between chronic conditions and the dependence of the elderly in BADL, no statistical significance was found in the evaluations performed. For IADL, a significant result was observed for systemic arterial hypertension $(p=0.018)$ and diabetes mellitus ( $p=0.023$ ), where the majority of the elderly were classified as independent. On the other hand, the elderly who reported gastrointestinal system disorders ( $p=0.015$ ) were considered to be dependent.

While none of the studies analyzed compared gastrointestinal problems with functional and instrumental capacity, a relationship was identified with the cardio and cerebrovascular conditions of the individuals surveyed ${ }^{11,24,27}$. Paiva et al. ${ }^{28}$, meanwhile, did not find a significant relationship between the presence of a morbidity and the functional capacity of the elderly.

When assessing the amount of morbidities reported by the elderly in relation to the presence of functional dependence in BADL $(p=0.097)$, greater dependence was observed in elderly persons with two morbidities and greater independence in individuals with one morbidity. Thus, it was not possible to identify the influence of number of morbidities on functional dependence.

This result differed from that obtained by Tavares and Dias ${ }^{29}$ who observed that a greater number of morbidities, as well as causing decline in the functional capacity of the elderly, directly affected their quality of life, especially in the psychological domain, due to the presence of negative feelings related to their physical state. It should be noted that the Tavares and Dias study was carried out with a much larger sample of 2,142 elderly persons, and focused on morbidity and dependence as a component of the quality of life of the elderly.

The evaluation of the elderly regarding the presence of dependence in IADL related to number of morbidities revealed significant results $(p=0.002)$. It was noted that all those who reported up to two morbidities were characterized, for the most part, as independent, while there was a smaller percentage difference between dependence and independence among those who had more than three morbidities.

Although the cross-sectional design does not allow us to establish that the morbidities caused dependence in IADL, it was noted that the percentage difference between dependent and independent individuals drops substantially as the number of reported morbidities increases.

This result is due to the number of elderly people who made up this research, as a larger sample is required to effectively identify such a relationship.

A study by Barnett et al. ${ }^{30}$ of $1,715,841$ people in the United Kingdom that evaluated the epidemiology of multi-morbidity, found that the greater the number of morbidities, the greater the decline in the physical abilities of the elderly. Pedrazzi et al. ${ }^{27}$, meanwhile, performed a study with 244 elderly persons living in the city of Ribeirão Preto, and found no relationship between the amount of morbidities and the functional capacity of people. There is therefore a need for larger samples to indicate an effective relationship between the number of morbidities and the functional capacity of the elderly.

Another limitation observed in this study was related to the types of morbidities found, as the study was performed based on the reports of the elderly about their morbidities. This type of data limits the analysis to perception, potentially masking morbidities that are often not considered by the elderly. It is suggested that an analysis of the elderly is performed with data from the medical records 
of health units to effectively identify more precise information about the subject.

However, there is a limitation in terms of the analysis of age of the present study. The age range remained very large ( \pm 40 years), establishing a major difference between the minimum and maximum age. It is therefore necessary to carry out a more profound analysis, stratifying the age groups to obtain a more detailed result on the subject.

\section{CONCLUSION}

According to the results obtained by the present study it is possible to conclude that elderly people living in the municipality of Herval d'Oeste, Santa Catarina are mostly independent.

The majority of the elderly $(86.1 \%$ of women and $82.4 \%$ of men) have at least one chronic disease undergoing treatment and elderly persons with more than two morbidities are more dependent in functional and instrumental activities of daily living.

The functional capacity activities in which the elderly persons demonstrated dependence were bathing, dressing and continence. Women were more dependent than men in all activities, and were most dependent in continence, while men are most dependent in dressing. There was a greater number

\section{REFERENCES}

1. Alves JED. Transição demográfica, transição da estrutura etária e envelhecimento. Rev Portal Divulg [Internet]. 2014 [acesso em 2014 ago. 20];4(40):8-15. Disponível em: http://www.portaldoenvelhecimento. org.br/revista

2. Ferreira TCR, Pinto DS, Pimentel KA, Peixoto Júnior O. Análise da capacidade funcional de idosos institucionalizados. Rev Bras Ciênc Envelhec Hum [Internet]. 2011 [acesso em 05 fev. 2014];8(1):9-20. Disponível em: http://www.upf.br/seer/index.php/ rbceh/article/view/387

3. Eliopoulos C. Enfermagem gerontológica. $5^{\text {a }}$.ed. Porto Alegre: Artmed; 2005. of totally dependent elderly people in the bathing and dressing activities in functional evaluation and the managing finances and cleaning the house activities in the instrumental evaluation.

In the instrumental activities, the elderly were found to be most dependent in managing finances and making purchases alone, with similar results for both genders.

Considering the characteristics of the aging process, with its multiple facets, the frailties imposed by this condition and the evaluation of the levels of independence of the elderly, there is a need for interventions from other areas in addition to health in the development of strategies to improve the process of caring for the elderly.

The present study encourages a wider discussion among health professionals regarding the prevention of and coping with dependencies. The challenge of learning to work in an integrated manner involves understanding the predisposing factors and focusing on one goal, which is the prevention of disability.

This study characterizes chronic diseases as a predisposing factor for dependence among the elderly. However, evaluating the elderly in an integral manner remains the most influential factor in the construction of cohesive care plans capable of preserving autonomy for a longer period.

4. Camargos MCS, Perpétuo IHO, Machado CJ. Expectativa de vida com incapacidade funcional em idosos em São Paulo, Brasil. Rev Panam Salud Pública [Internet]. 2005 [acesso em 19 jan. 2016];17(5/6):37986. Disponível em:http://www.scielosp.org/scielo. php?pid $=$ S1020-49892005000500010\&script $=$ sci_ abstract\&tlng $=\mathrm{pt}$

5. Instituto Brasileiro de Geografia e Estatística. Síntese de Indicadores Sociais: uma análise das condições de vida [Internet]. Rio de Janeiro: IBGE; 2013 [acesso em 25 fev. 2015]. Disponível em:http://biblioteca. ibge.gov.br/visualizacao/livros/liv66777.pdf 
6. Pilger C, Menon MH, Mathias TAF. Características sociodemográficas e de saúde de idosos: contribuições para os serviços de saúde. Rev Latinoam Enferm [Internet]. 2011 [acesso em 19 jan 2016];19(5):12308. Disponível em: http://www.scielo.br/scielo. php?pid=S0104-11692011000500022\&script $=$ sci_ arttext\&tlng=pt

7. Freitas MC, Queiroz TA, Sousa JAV. O significado da velhice e da experiência de envelhecer para os idosos. Rev Esc Enferm USP [Internet]. 2010 [acesso em 11 set. 2014];44(2):407-12. Disponível em: http:// www.scielo.br/scielo.php?script=sci_arttext\&pid $=$ S0080-62342010000200024

8. Britto TA, Fernandes MH, Coqueiro RS, Jesus CS. Quedas e capacidade funcional em idosos longevos residentes em comunidade. Texto \& Contexto Enferm [Internet]. 2013 [acesso em 05 fev. 2014];22(1):43-51. Disponível em:http://www.scielo. br/pdf/tce/v22n1/pt_06.pdf

9. Carvalho JAM, Garcia RA. O envelhecimento da população brasileira: um enfoque demográfico. Cad. Saúde Pública [Internet]. 2003 [acesso em 22 ago. 2014];3(19):725-33. Disponível em: http://www. scielosp.org/pdf/csp/v19n3/15876.pdf

10. Nogueira SL, Ribeiro RCL, Rosado LEFPL, Franceschini SCC, Ribeiro AQ, Pereira ET. Fatores determinantes da capacidade funcional em idosos longevos. Rev Bras Fisioter [Internet]. 2010 [acesso em 28 out. 2014];14(4):322-9. Disponível em: http:// www.scielo.br/scielo.php?script=sci_arttext\&pid =\$1413-35552010000400009

11. Soares MBO, Tavares DMS, Dias FA, Diniz MA, Geib S. Morbidade, capacidade funcional e qualidade de vida de mulheres idosas. Esc Anna Nery [Internet]. 2010 [acesso em 29 dez.2015];14(4):705-11. Disponível em: http://www.scielo.br/scielo.php?pid=S1414$81452010000400008 \&$ script $=$ sci_arttext

12. Duarte MCS, Fernandes MGM, Rodrigues RAP, Nóbrega MML. Prevalência e fatores socioeconômicos associados à fragilidade em mulheres idosas. Rev Bras Enferm [Internet]. 2013 [acesso em 04 fev. 2016];66(6):901-6. Disponível em: http://www.scielo.br/scielo.php?pid=S003471672013000600014\&script=sci_arttext

13. Fialho CB, Lima-Costa MF, Giacomin KC, Loyola Filho AI. Capacidade funcional e uso de serviço de saúde por idosos da Região metropolitana de Belo Horizonte, Minas Gerais, Brasil: um estudo de base populacional. Cad Saúde Pública [Internet]. 2014 [acesso em 02 fev. 2016];30(3):599-610. Disponível em: http://www.scielo.br/pdf/csp/v30n3/0102311X-csp-30-3-0599.pdf
14. Barbosa BR, Almeida JM, Barbosa MR, Rossi- Barbosa LAR. Avaliação da capacidade funcional dos idosos e fatores associados à incapacidade. Ciênc Saúde Coletiva [Internet]. 2014 [acesso em 03 fev. 2016];19(8):331725. Disponível em: http://www.scielo.br/scielo. php?pid=S1413-81232014000803317\&script $=$ sci_arttext

15. Kagawa CA, Corrente JE. Análise da capacidade funcional em idosos do município de AvaréSP: fatores associados. Rev Bras Geriatr Gerontol [Internet]. 2015 [acesso em 29 jan. 2016];18(3):577-86. Disponível em: http://www. scielo.br/scielo.php?script $=$ sci_arttext\&pid $=$ S1809_ 98232015000300577\&lng=en\&nrm $=$ iso

16. Assis VG, Marta SN, Conti MHS, Gatti MAN, Simeão SFAP, Vitta A. Prevalência e fatores associados à capacidade funcional de idosos na Estratégia Saúde da Família em Montes Claros, Minas Gerais, Brasil. Rev Bras Geriatr Gerontol [Internet]. 2014 [acesso em 29 jan. 2016];17(1):15363. Disponível em: http://www.scielo.br/pdf/rbgg/ v17n1/1809-9823-rbgg-17-01-00153.pdf

17. Fernandes HCL. O acesso aos serviços de saúde e sua relação com a capacidade funcional e a fragilidade em idosos atendidos pela estratégia saúde da família [dissertação]. São Paulo: Universidade de São Paulo; 2010.

18. Gasparini EMT. Uso de dispositivos assistidos por idosos mais velhos domiciliados e sua relação com a capacidade funcional e com a fragilidade [Dissertação]. Ribeirão Preto: Universidade de São Paulo; 2015.

19. Diamante C, Murbach LD, Danielli C, Zilio M, Comparin KA, Frare JC. Impacto da incontinência urinária na qualidade de vida de mulheres submetidas a tratamento fisioterápico de biofeedback manométrico. Cad Educ Saúde Fisioter [Internet]. 2015 [acesso em 12 jan 2016];2(3):711-23. Disponível em: http://revista. redeunida.org.br/ojs/index.php/cadernos-educacaosaude-fisioterapia/article/view/411

20. Brito KQD, Menezes TN, Olinda RA. Incapacidade funcional e fatores socioeconômicos e demográficos associados em idosos. Rev Bras Enferm [Internet]. 2015 [acesso em 09 fev. 2016];68(4):633-41. Disponível em: http://www.scielo.br/scielo.php?script=sci_ arttext\&pid $=$ S0034-71672015000400633\&lng=pt\&nr $\mathrm{m}=$ iso\&tlng=en

21. Silva NA, Menezes TN. Capacidade funcional e sua associação com idade e sexo em uma população idosa. Rev Bras Cineantropom Desempenho hum [Internet]. 2014 [acesso em 09 fev. 2016];16(3):35970. Disponível em: http://www.scielo.br/scielo. php?pid $=$ S1980-00372014000300359\&script $=$ sci_ abstract\&tlng=es 
22. Costa EC, Nakatani AYK, Bachion MM. Capacidade de idosos da comunidade para desenvolver atividades de vida diária e atividades instrumentais de vida diária. Acta Paul Enferm [Internet]. 2006 [acesso em 25 jan. 2016];19(1):43-8. Disponível em: http://www.scielo.br/scielo.php?script $=$ sci_ arttext\&pid $=$ S0103-21002006000100007\&lng=pt\&n $\mathrm{rm}=$ iso\&tlng $=\mathrm{pt}$

23. Alvarenga MRM. Avaliação da capacidade funcional, do estado funcional e da rede de suporte social do idoso atendido na Atenção Básica [tese na Internet]. São Paulo: Universidade de São Paulo; 2008 [acesso em 14 set. 2014]. Disponível em: http://www.teses. usp.br/teses/disponiveis/7/7136/tde-07052009083059/pt-br.php

24. Santos GS, Cunha ICK. O. Avaliação da capacidade funcional de idosos e desempenho das atividades instrumentais da vida diária: um estudo na atenção básica em saúde. Rev Enferm Cent.-Oeste Min [Internet]. 2013 [acesso em 05 fev. 2016];3(3):820-8. Disponível em: http://www.seer.ufsj.edu.br/index. php/recom/article/viewArticle/421

25. Oliveira BLCA, Barros MMP, Baima VJD, Cunha CLF, Silva AM. Avaliação das atividades instrumentais de vida diária em idosos da periferia de São Luis, Maranhão. J Manag Prim Health Care [Internet]. 2012 [acesso em 05 fev 2016];3(10):43-7. Disponível em: http://www.jmphc.com/ojs/index. $\mathrm{php} / 01 /$ article/viewArticle/29
26. Souza CC, Valmorbida JA, Oliveira JP, Borsatto AC, Lorenzini M, Knorst MR, et al. Mobilidade funcional em idosos institucionalizados e não institucionalizados. Rev Bras Geriatr Gerontol [Internet]. 2013 [acesso em 05 fev. 2016];16(2):285-93. Disponível em: http:// www.scielo.br/scielo.php?script=sci_arttext\&pid $=$ =1809-98232013000200008

27. Pedrazzi EC, Rodrigues RAP, Schiaveto FV. Morbidade referida e capacidade funcional. Ciênc Cuid Saúde [Internet]. 2007 [acesso em 29 dez 2015];6(4):407-13. Disponível em: http://www.periodicos.uem.br/ojs/ index.php/CiencCuidSaude/article/view/3391

28. Paiva SCL, Gomes CP, Almeira LG, Dutra RR, Aguiar NP, Lucinda LMF, et al. Influência das comorbidades, do uso de medicamentos e da institucionalização na capacidade funcional dos idosos. Rev Interdiscipl Estud Exp [Internet]. 2014 [acesso em 04 fev 2016];6:46-53. Disponível em: http://riee.ufjf. emnuvens.com.br/riee/article/view/2859

29. Tavares DMS, Dias FA. Capacidade funcional, morbidades e qualidade de vida de idosos. Texto \& Contexto Enferm [Internet]. 2012 [acesso em 06 fev. 2014];21(1):112-20. Disponível em: http://www. redalyc.org/articulo.oa?id=71422299013

30. Barnett K, Mercer SW, Norbury M, Watt G, Wyke S, Guthri B. Epidemiology of multimorbidity and implications for healthcare, research, and medical education: a cross-sectional study [abstract]. Lancet [Internet]. 2012 [acesso em 30 set. 2015];380(9836):1. Disponível em: http://www.thelancet.com/journals/ lancet/article/PIIS0140-6736(12)60240-2/abstract 